\title{
GMR
}

\section{Genetic effect of an $A / G$ polymorphism in the HSP70 gene on thermotolerance in chicken}

\author{
Z.Y. Chen ${ }^{1,2}$, W.W. Zhang ${ }^{1,2}$, J.K. Gan ${ }^{1,2}$, L.N. Kong ${ }^{1,2}$, X.Q. Zhang ${ }^{1,2}$, \\ D.X. Zhang ${ }^{1,2}$ and Q.B. Luo ${ }^{1,2}$ \\ ${ }^{1}$ College of Animal Science, South China Agricultural University, \\ Guangzhou, China \\ ${ }^{2}$ Key Lab of Chicken Genetics, Breeding and Reproduction, \\ Ministry of Agriculture, South China Agricultural University, Guangzhou, China \\ Corresponding author: Q.B. Luo \\ E-mail: qbluo@scau.edu.cn
}

Genet. Mol. Res. 15 (2): gmr.15028271

Received August 8, 2015

Accepted November 26, 2015

Published July 15, 2016

DOI http://dx.doi.org/10.4238/gmr.15028271

\begin{abstract}
Studying thermotolerance is important for the prevention of thermostress in chickens. This study aimed to analyze the effect of mutations in the heat shock protein 70 (HSP70) gene on chicken thermotolerance. The C.-69A $>$ G SNP in the 5'-flanking region of the HSP70 gene was genotyped in Lingshan and White Recessive Rock (WRR) chickens. Association of this SNP with thermotolerance traits revealed it to be significantly associated with $\mathrm{CD} 4+/ \mathrm{CD} 8+$, and potentially associated with heterophil-to-lymphocyte ratio in WRR chickens exposed to thermoneutral temperature $\left(15^{\circ} \mathrm{C}\right)$. Online prediction detected a putative myeloid zinc finger protein 1 binding factor in the C.-69A $>\mathrm{G}$ mutation. Under acute thermostress, mRNA levels of $H S P 70$ in individuals with different C.-69A $>\mathrm{G}$ genotypes varied in the heart, leg muscle, and liver tissues. The HSP70 protein was expressed at higher levels in individuals with the GG genotype than in those with the AA genotype. In heart and liver, protein expression of HSP70 in individuals with the GG genotype was significantly higher than in those with the AA genotype. In leg muscle, protein expression
\end{abstract}


was higher in birds with the GG genotype than in those with the AA and AG genotypes. Luciferase activity of the GG genotype was significantly higher than that of the AA genotype, suggesting that the C.-69A $>$ G SNP regulates $H S P 70$ gene expression. These results indicate that the C.-69A $>$ G SNP in the 5'-flanking region of the HSP70 gene might affect chicken thermotolerance and that the GG genotype might be advantageous for the prevention of thermostress.

Key words: Chicken HSP70 gene; Thermotolerance traits; mRNA expression; Western blotting; Dual-luciferase reporter assay

\section{INTRODUCTION}

Heat stress is one of the most challenging environmental conditions affecting commercial poultry. In the summer, high temperatures can lead to increased mortality, reduced feed intake, growth rate, and egg shell quality, as well as lower weight gain and egg production in domestic birds (Cahaner et al., 2008; Melesse et al., 2011). Consequently, substantial economic losses in the poultry industry are often observed (Rozenboim et al., 2007). Additionally, pale, soft exudative-like changes in meat quality have been observed in broilers exposed to acute or chronic heat stress, pre-slaughter (Sandercock et al., 2001; Lu et al., 2007). Like all living organisms, chickens possess mechanisms that protect them against environmental challenges. Heat shock proteins (HSPs) are a family of proteins synthesized in response to physical, chemical, or biological stresses, including heat exposure (Staib et al., 2007). HSPs are a group of evolutionarily conserved proteins that are conventionally classified according to their size, which ranges from 10 to $150 \mathrm{kDa}$ (Benjamin and McMillan, 1998). HSPs act as molecular chaperones during protein assembly and disassembly (Hartl and Hayer-Hartl, 2002), protein folding and unfolding (Hartl, 1996), protein translocation (Ryan and Pfanner, 2001; Zhang et al., 2006), and the refolding of damaged proteins (Marques et al., 2006). HSPs play important roles in the protection and repair of cells and tissues. In addition, the overexpression of one or more HSP genes helps to protect cells against subsequent stress (Zhang and Sarge, 2007).

Some studies have shown that 3,5,3'-triiodothyronine $\left(\mathrm{T}_{3}\right)$ and corticosterone may be considered as physiological indices for evaluating thermotolerance traits. Hangalapura et al. (2004) showed that 1 day of cold stress significantly enhanced $T_{3}$ levels; however, there was no effect on $\mathrm{T}_{3}$ levels when the birds were cold stressed for a long period. Bedanova et al. (2007) and Zulkifli et al. (2009) found that corticosterone plasma concentrations were elevated in broilers that were shackled and heat stressed, respectively. In addition to $\mathrm{T}_{3}$ and corticosterone, other physiological indices (e.g., $\mathrm{CD} 3+, \mathrm{CD} 4+$, and $\mathrm{CD} 8+\mathrm{T}$ ) may also be used to evaluate thermotolerance traits. Cluster of differentiation (CD) is used to identify and investigate cell surface molecules present on white blood cells, and can also be found in almost any type of cell in the body, thus providing targets for the immunophenotyping of cells. Khajavi et al. (2003) found that heat stress decreased the level of CD4+ and CD8+ expressing T cell levels, while feed restriction elevated CD4+ and decreased CD8+T cell levels.

Previous studies have shown that HSPs are expressed in a time- and tissue-specific manner, which is often variable. Using western blot analysis, Leandro et al. (2004) detected the HSP70 protein in all embryo tissues (Hubbard strain and Ross 308 strain). Brain tissue was found to contain 2-5-fold higher levels of HSP70 when compared to other tissues in either cold 
or heat stressed embryos. In addition, Zhen et al. (2006) found that the expression of HSP70 mRNA in the brain was higher than that in the liver and leg muscle. Jost et al. (2012) noted that changes in HSP70 expression varied in decapod crustaceans and whiteflies, and that HSP70 plays an important role in the thermotolerance of these species.

Although numerous studies have evaluated the function of HSP70, no studies have investigated the association of polymorphisms in this gene with thermotolerance traits in chickens. Therefore, the aim of the current study was to analyze the genetic effect of the single nucleotide polymorphism (SNP) C.-69A $>\mathrm{G}$ in the $H S P 70$ gene on chicken thermotolerance. In this study, we studied the C.-69A $>$ G site in the 5'-flanking region of the HSP70 gene and its association with thermotolerance traits under different conditions. Finally, luciferase expression assays were performed for different genotypes of this mutation.

\section{MATERIAL AND METHODS}

\section{Animal samples and the design of thermostress experiment}

A total of 330 female chickens from 2 chicken breeds, including 160 thirty-fourweek-old White Recessive Rock (WRR) and 170 thirty-week-old Lingshan (LS) chickens, were obtained from Guangdong Wen's Southern Poultry Breed Company. Blood samples $(5 \mathrm{~mL})$ were obtained at $35^{\circ}$ and $15^{\circ} \mathrm{C}$, and were then used to isolate genomic DNA using a phenol-chloroform extraction method, and index determination of thermotolerance traits $\left[\mathrm{T}_{3}\right.$, heterophil-to-lymphocyte ratio $(\mathrm{H} / \mathrm{L})$, corticosterone, $\mathrm{CD} 3+$, and $\left.\mathrm{CD} 4+/ \mathrm{CD} 8+\right]$, which measured heat resistance of chicken.

A total of 100 female birds, including 50 WRR and 50 LS birds, were obtained from Guangdong Wen's Southern Poultry Breed Company. At 1 day of age, chickens were housed in large coops (20 birds per coop) and the coops were placed in a controlled climate chamber and allowed 1-week to acclimatize to their new surroundings and to recover from any environmental stress. During this period, the broilers were reared under standard conditions. The relative humidity of the chamber was maintained at $60 \pm 10 \%$. The room temperature (RT) was maintained at $34^{\circ} \pm 1^{\circ} \mathrm{C}$ from days 1 to 3 . As the chickens grew, the RT was decreased gradually and maintained at $25^{\circ} \pm 1{ }^{\circ} \mathrm{C}$ by controlled ventilation and heating until day 7 . At 8 days of age, the RT sharply increased from $25^{\circ} \pm 1^{\circ} \mathrm{C}$ to $40^{\circ} \pm 1^{\circ} \mathrm{C}$. The temperature was routinely monitored via measurements taken from the center of each coop. The relative humidity of the chamber during the thermostress condition was maintained at $50 \pm 5 \%$. The birds were given access to a commercial broiler feed and water ad libitum throughout the period of thermostress. Upon termination of thermal treatment, blood samples $(2 \mathrm{~mL})$ were repackaged into blood collection tubes for genomic DNA isolation and each bird was sacrificed by decapitation. Following exsanguination, the birds were manually eviscerated, and the heart, liver, and leg muscle were quickly dissected and placed into $2-\mathrm{mL}$ tubes. The tubes were placed in liquid nitrogen, and then stored at $-80^{\circ} \mathrm{C}$ until subsequent extraction of total RNA. The experiment was undertaken in accordance with, and approved by, the Animal Care Committee of South China Agricultural University (Guangzhou, China) (approval ID: SCAU\#0011).

\section{Measurements of thermotolerance traits}

$\mathrm{T}_{3}$ and corticosterone were measured by enzyme-linked immunosorbent assay 
(ELISA) following the manufacturer instructions. The H/L ratio was counted by the People's Liberation Army Hospital 458 (Guangzhou, China), and the expression levels of CD3+, CD4+, and CD8+T were analyzed using flow cytometry.

\section{Primer design, PCR amplification, and polymorphism identification}

PCR primers for the HSP70 (GenBank accession No. J02579) and $\beta$-actin genes were designed based on reference sequences. Information on these primers is presented in Table 1. P1 primers were used to amplify 654-bp fragments of the HSP70 gene. P2 (HSP70 mRNA primers) and $\mathrm{P} 3$ ( $\beta$-actin primers) primers were used for fluorescent quantitative real-time PCR (qRT-PCR).

\begin{tabular}{|c|c|c|c|}
\hline & Primers sequences $\left(5^{\prime}-3^{\prime}\right)$ & Annealing temperature $\left({ }^{\circ} \mathrm{C}\right)$ & Products (bp) \\
\hline \multirow[t]{2}{*}{ P1 } & F: ATTGTCCTTAGCGTTCT & \multirow[t]{2}{*}{62} & \multirow[t]{2}{*}{654} \\
\hline & R: TCTTCATCTCACCCTTGTAC & & \\
\hline \multirow[t]{2}{*}{ P2 } & F: GTAGAAGAGTTCAAGCGTAAG & \multirow[t]{2}{*}{57} & \multirow[t]{2}{*}{166} \\
\hline & R: TGGAGGTGTAGAAGTCAATG & & \\
\hline \multirow[t]{2}{*}{ P3 } & F: CTCCCCCATGCCATCCTCCGTCTG & \multirow[t]{2}{*}{57} & \multirow[t]{2}{*}{179} \\
\hline & R: GCTGTGGCCATCTCCTGCTC & & \\
\hline \multirow[t]{2}{*}{ A-69G } & F: CGGggtaccCGATCTGGCTGCAATCTACGGGA & \multirow[t]{2}{*}{55} & \multirow[t]{2}{*}{310} \\
\hline & R: $\underline{\text { CGGctcgagGATGATAGATTCCTCTTGGTCAG }}$ & & \\
\hline
\end{tabular}

Underlined letters represent protective bases. Lower-case letters represent restriction enzyme sites.

PCR was performed in $25-\mu \mathrm{L}$ volumes containing 50 ng genomic DNA, $200 \mu \mathrm{M}$ diethylnitrophenyl thiophosphates (dNTPs), $1 \mathrm{X}$ buffer, $2 \mathrm{mM} \mathrm{MgCl}, 1 \mu \mathrm{M}$ each primer, and 1.5 U Taq DNA polymerase (Shanghai Biological Engineering Company, China). The following PCR protocol was used to amplify the HSP70 gene: initial amplification by incubating the PCR mixture at $94^{\circ} \mathrm{C}$ for $3 \mathrm{~min}$, following by 32 cycles of incubation at $94^{\circ} \mathrm{C}$; annealing temperatures of $62^{\circ} \mathrm{C}$ for $30 \mathrm{~s}$ and $72^{\circ} \mathrm{C}$ for $30 \mathrm{~s}$; and a final incubation at $72^{\circ} \mathrm{C}$ for 4 min. PCR products were subjected to $1.2 \%$ agarose gel electrophoresis and visualized using a TFM-40 Ultraviolet Transilluminator (UVP Company, Cambridge, UK) by ethidium bromide staining. DNA sequencing was performed by the dideoxy chain-termination method using dye terminator cycle sequencing in an Applied Biosystem model 3730 sequencer. Sequence analysis was conducted using the DNASTAR V 3.0 software (http://www.biologysoft.com/; Steve ShearDown, 1998-2001 version reserved by DNASTAR Inc., Madison, WI, USA).

\section{RNA extraction and cDNA synthesis}

The heart, liver, and leg muscle tissues were collected from 100 eight-day-old broilers. Total RNA was extracted with the TRIzol reagent (Invitrogen, Carlsbad, CA, USA) following the manufacturer instructions and then treated with DNase (Promega, Madison, WI, USA). The DNase reaction included $1 \mu \mathrm{g}$ total RNA, $1 \mathrm{U}$ RNase-free DNase, $1 \mu \mathrm{L} 10 \mathrm{X}$ reaction buffer, and $7 \mu \mathrm{L}$ nuclease-free water. The mixture was incubated at $37^{\circ} \mathrm{C}$ for $30 \mathrm{~min}$, followed by denaturation at $65^{\circ} \mathrm{C}$ for $10 \mathrm{~min}$, and snap cooled on ice for $2 \mathrm{~min}$. The quality and purity of the RNA were confirmed by agarose gel electrophoresis and spectrophotometry. cDNA was synthesized in a final volume $20 \mu \mathrm{L}$ including $1 \mu \mathrm{g}$ total RNA, 1X MMLV Buffer, $1 \mathrm{mM}$ each dNTP, $2.5 \mu \mathrm{M}$ oligo (dT)18, $0.5 \mu \mathrm{L}(40 \mathrm{U} / \mu \mathrm{L})$ RNase inhibitor, and $100 \mathrm{U}$ MMLV SuperScript 
III reverse transcriptase (Invitrogen). Reverse transcription was performed for $40 \mathrm{~min}$ at $42^{\circ} \mathrm{C}$, followed by heating for $5 \mathrm{~min}$ at $95^{\circ} \mathrm{C}$, and samples were then cooled on ice.

\section{qRT-PCR}

qRT-PCR was performed with a CFX96 Real-Time PCR Detection System (Bio-Rad, USA) using SYBR Green PCR Master Mix. The obtained cDNAs were used as templates for qPCR amplification with the primers P2 and P3 (Table 1), and the chicken $\beta$-actin gene was used as an internal control. Each reaction mixture contained $10 \mu \mathrm{L}$ SYBR Green PCR Master Mix, $2 \mu \mathrm{L}$ each primer $(10 \mu \mathrm{M}), 4 \mu \mathrm{L}$ ultrapure RNase-free water, and $2 \mu \mathrm{L}$ cDNA in a final volume $20 \mu \mathrm{L}$. Standard amplification conditions were as follows: $95^{\circ} \mathrm{C}$ for $3 \mathrm{~min}$; 40 cycles of $95^{\circ} \mathrm{C}$ for $30 \mathrm{~s}, 57^{\circ} \mathrm{C}$ for $30 \mathrm{~s}$, and $72^{\circ} \mathrm{C}$ for $40 \mathrm{~s}$. Fluorescent signals were collected after the extension at $72^{\circ} \mathrm{C}$ in each cycle. The entire experiment was repeated at least three times. After amplification, dissociation curve analysis was conducted to ensure that only one product was obtained. The product was then sequenced to confirm amplification of the correct sequences.

\section{Protein determination and electrophoresis}

Tissues samples $(1 \mathrm{~g})$ were homogenized in $50-\mathrm{mL}$ polypropylene centrifuge tubes using $10 \mathrm{~mL}$ lysis buffer ( $20 \mathrm{mM}$ Tris-HCl, $\mathrm{pH} 7.5 ; 0.9 \% \mathrm{NaCl} ; 2 \mathrm{mM} \beta$-mercaptoethanol). Samples were homogenized three times $(30 \mathrm{~s}$ each) using an Ultra-turrax homogenizer at $20,000 \mathrm{rpm}$ and placed in an ice-bath for 30-s intervals. The lysate was centrifuged at 31,000 $g$ for $30 \mathrm{~min}$ at $4^{\circ} \mathrm{C}$. The supernatant was transferred to $15-\mathrm{mL}$ polypropylene tubes and manually homogenized 10 times using a Potter-Elvehjem homogenizer. Two $300-\mathrm{mL}$ aliquots were separated for total protein determination and electrophoresis. Three hundred microliters of sample buffer [125 mM Tris-HCl, $\mathrm{pH} 6.8 ; 40 \%$ glycerol; 8\% SDS (sodium dodecyl sulfate); $0.002 \%$ bromophenol blue] and $40 \mu \mathrm{L} \beta$-mercaptoethanol were added to the electrophoresis samples, which were boiled for $2 \mathrm{~min}$ and stored at $-20^{\circ} \mathrm{C}$ until electrophoresis. The concentration of protein in supernatant aliquots was determined in quintuplicate according to the method described by Hartree (1972). A standard curve was produced using bovine serum albumin (BSA1, Sigma, Aldrich-Chemical Representações Ltda., São Paulo, SP, Brazil) in triplicate samples $0,20,40,60,80$, and $100 \mathrm{mg}$ (Figure 1). Thirty micrograms of total protein was loaded onto $9 \%$ polyacrylamide gels containing SDS and separated by electrophoresis (Laemmli, 1970), using the Mini-Protean II apparatus (Bio-Rad) at a constant voltage (200 V). Before loading, the samples were boiled for $2 \mathrm{~min}$, and a sample of the supernatant derived from the control birds was loaded on all gels, as a reference standard. A prestained molecular weight standard (Gibco-BRL, Carlsbad, CA, USA) was used on all gels.

\section{Western blotting}

After fractionation on SDS polyacrylamide gels, proteins were electrophoretically transferred to polyvinylidene difluoride (PVDF) membranes (Amersham, Buckinghamshire, UK) using the procedure described by Towbin et al. (1979). The transfer was performed for 30 min at a constant voltage $(90 \mathrm{~V})$ using a mini-transblot cell (Bio-Rad). The membranes were stained with $0.5 \%$ Ponceau $\mathrm{S}$ in $1 \%$ acetic acid for 3 min to confirm the transfer of proteins. After washing several times with deionized water, nonspecific interaction sites were blocked 
using $10 \mathrm{~mL}$ cold TBS buffer (10 mM Tris-HCl, $\mathrm{pH} 8.0,150 \mathrm{mM} \mathrm{NaCl})$ containing $5 \%$ nonfat dried milk and $0.05 \%$ Tween-20, on a shaker $(\sim 100 \mathrm{rpm})$ for $1 \mathrm{~h}$ at room temperature. The membranes were then incubated with monoclonal anti-HSP70 antibody (H-5157, Sigma) in $10 \mathrm{~mL}$ cold TBS-milk solution (1:1000 dilution) containing $0.05 \%$ Tween-20 for $1 \mathrm{~h}$ at room temperature with constant shaking. Four washings of 5 min each using $10 \mathrm{~mL}$ TBST ( $10 \mathrm{mM}$ Tris- $\mathrm{HCl}, \mathrm{pH} 8.0,150 \mathrm{mM} \mathrm{NaCl}, 0.05 \%$ Tween-20) and a 10 -min wash using $10 \mathrm{~mL}$ cold TBS buffer were performed. The membranes were incubated with 2-mL secondary antimouse antibody conjugated to alkaline phosphatase (A-5153, Sigma) diluted in $10 \mathrm{~mL}$ cold TBS-milk solution (1:5000 dilution) for $1 \mathrm{~h}$ at room temperature with constant shaking. After rinsing with cold TBST and TBS, as described above, the color was developed for 2 min using 33 $\mathrm{mL}$ nitro-blue tetrazolium chloride solution $(50 \mathrm{mg} / \mathrm{mL}$ in dimethylformamide) and $66 \mathrm{~mL}$ 5-bromo-4-chloro-3-indolylphosphate p-toluidine $(50 \mathrm{mg} / \mathrm{mL}$ in $70 \%$ dimethylformamide) added to $10 \mathrm{~mL}$ alkaline phosphatase buffer $(100 \mathrm{mM}$ Tris-HCl, $\mathrm{pH} 9.5,100 \mathrm{mM} \mathrm{NaCl}, 5 \mathrm{mM}$ $\mathrm{MgCl}_{2}$ ). Nonspecific binding was blocked by the addition of a solution of $30 \%$ trichloroacetic acid. The membranes were washed with deionized water and dried at room temperature, protected from light. The intensity of the bands corresponding to HSP70 was analyzed using a densitometer at $525 \mathrm{~nm}$ (Shimadzu CS-9301) using reflection model and zigzag scanning; HSP70 quantification was conducted according to the method described by Givisiez et al. (1999). The levels of HSP70 are reported as ng/mg of total protein (Figure 1).

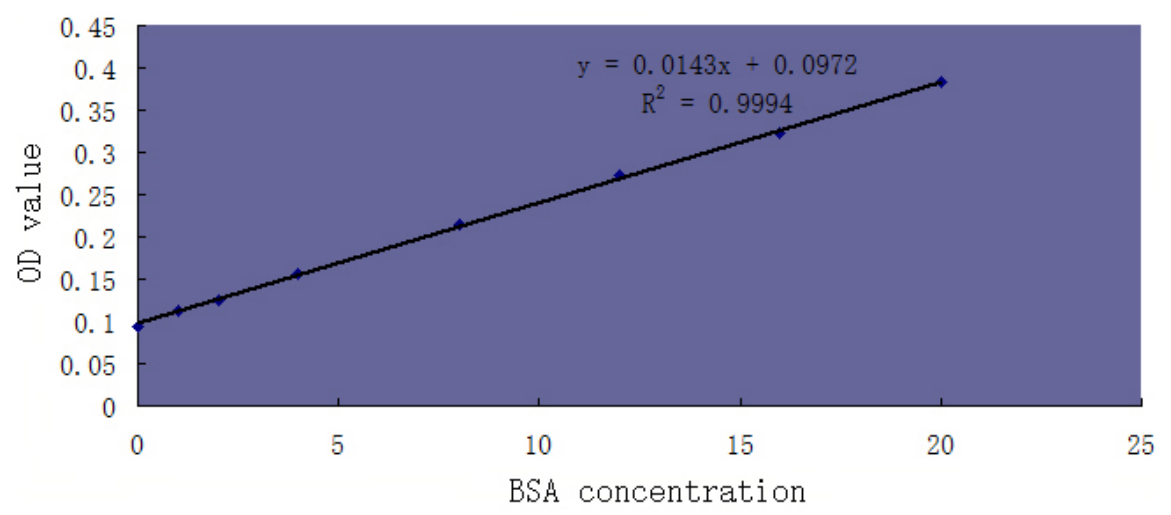

Figure 1. Bovine serum albumin (BSA) standard curve.

\section{Luciferase expression constructs and luciferase expression assays}

A pGL3-promoter vector (Promega) was double-digested with restriction enzymes and used to ligate the truncated amplification products of the 5'-flanking region of the HSP70 gene in order to determine the core promoter. Two expression vectors, pC.-69A $>$ G-AA and pC.-69A $>$ G-GG, were constructed. The A-69G primers were used to amplify the 5'-flanking region of the HSP70 gene (Table 1). The PCR products were ligated into the pGL3-promoter vector between the KpnI and $\mathrm{XhoI}$ sites. The plasmids were then transfected into chicken embryo fibroblasts at a density 1 × $10^{5}$ cells/well. The QuikChange Site-Directed Mutagenesis Kit (Stratagene) was used to alter SNP alleles. All constructs were verified by DNA sequencing following the manufacturer manual, the plasmids were transfected into chicken 
embryo fibroblasts at a density $1 \times 10^{4}$ cells/well. A 24 -well plate containing $500 \mu \mathrm{L}$ medium containing $5 \%$ serum per well was used. A total of $1 \mu \mathrm{g}$ plasmid pGL3 vector and $500 \mathrm{ng} \mathrm{pRL}-$ TK internal control vector (Promega) were co-transfected into cells using Lipofectamine ${ }^{\mathrm{TM}}$ 2000 (Invitrogen). After $5 \mathrm{~h}$, the medium was changed to fresh medium with $10 \%$ fetal bovine serum. The cells were then incubated for $12 \mathrm{~h}$, and luciferase assays were performed according to the manufacturer instructions (Promega). Luciferase activity was normalized using pRLTK activity. Each experiment was performed six times.

\section{Statistical analysis}

\section{Genotyping and prediction of transcription factor binding sites for the SNP C. $A-69>G$}

DNAMAN (Lynnon Biosoft) was used for DNA contig assembly, sequence editing, and sequence translation. The identification of mutated sites was performed using the MegAlign program of the DNASTAR software (http://www.biologysoft.com/; Steve ShearDown, 1998-2001 version reserved by DNASTAR Inc.). The potential transcription factor binding sites of C.-69A $>\mathrm{G}$ were predicted using two bioinformatic websites, including http://motif. genome.jp and http://www.gene-regulation.com/pub/programs/alibaba2, following the setting parameters. Comparable results obtained by the two websites were selected.

\section{Gene frequency, genotype frequency, and Hardy-Weinberg equilibrium}

Genotypic frequency was determined as:

$$
(\text { FAiAj })=(\text { AiAj number of individuals / samples of a population }) \times 100 \% \quad \text { (Equation } 1)
$$

Gene frequency was determined as:

$$
(\text { Fai })=\text { FAiAi }+1 / 2 \Sigma F A i A j(i \neq j)
$$

FAiAj indicates the gene frequency of AiAj on locus A; Fai indicates the frequency of allele Ai on locus A. The multiple comparisons for genotypic frequency of C. $-69 \mathrm{~A}>\mathrm{G}$ in the two populations were performed using the GLM process of SAS 8.2 and Duncan's LSR. Hardy-Weinberg equilibrium testing of the C.A- $69>\mathrm{G}$ genotype was tested by the HWSIM procedure (http://krunch.med.yale.edu/hwsim/).

\section{Association analyses}

Association analysis I investigated SNP C.-69A $>\mathrm{G}$ and thermotolerance traits; association analysis II investigated SNP C.-69A $>\mathrm{G}$ and expression levels of HSP70 mRNA and HSP70 protein in three tissues from thermo-stressed broilers.

The association analyses were performed using the GLM process of SAS 8.2 with the following model:

$$
\mathrm{Y}_{\mathrm{ij}}=\mu+\mathrm{G}_{\mathrm{i}}+\mathrm{E}_{\mathrm{ij}}
$$

where, $Y_{i j}$ is the phenotype value of thermotolerance traits, $\mu$ is the mean value, $G_{i}$ is the fixed 
effect of $\mathrm{i}^{\text {th }}$ genotype, and $E_{i j}$ is the residual effect.

\section{RESULTS}

\section{Determination of gene frequency, genotype frequency, and Hardy-Weinberg equilibrium}

Using the P1 primer, a 654-bp fragment, including $322 \mathrm{bp}$ of the 5'-flanking region and $322 \mathrm{bp}$ of the coding region, of the HSP70 gene was obtained. One SNP, C.-69A $>\mathrm{G}$, was identified in the 5'-flanking region. Online transcription factor binding site prediction identified a putative myeloid zinc finger protein 1 (MZF1) binding factor in the mutated sequence C.$69 \mathrm{~A}>\mathrm{G}$ (core sequence: ggagggga).

The number of LS chickens with the AA, AG, and GG genotypes was 85, 68, and 17, respectively. The number of WRR chickens with AA, AG, and GG genotypes was 134, 24, and 2 , respectively. The AA genotype was observed at higher frequency in WRR chickens than in LS chickens, while the GG genotype frequency in WRR chickens was only 0.01 (Table 2). An independence test for the C.-69A $>\mathrm{G}$ site indicated that the genotype distribution in LS chickens was significantly different from that in WRR chickens $\left(\chi^{2}=43.5860, \mathrm{P}<0.01\right)$. Goodness of fit revealed that the C.-69A $>$ G site was found to be in Hardy-Weinberg equilibrium in those two populations, which suggests that these two populations either experienced no direct or indirect selection at the C. $-69 \mathrm{~A}>\mathrm{G}$ site, or that a balanced state was achieved under selection (Table 2). Thus, the C.-69A $>\mathrm{G}$ was subjected to a random-mating state.

Table 2. Gene and genotype frequency, and Hardy-Weinberg equilibrium of the C.-69A $>$ G single nucleotide polymorphism.

\begin{tabular}{l|c|c|c|c|c}
\hline Site & Allele and genotype & LS (170) & LS $\chi^{2}$ & WRR (160) & WRR $\chi^{2}$ \\
\hline \multirow{2}{*}{ C.-69A $>\mathrm{G}$} & $\mathrm{A} / \mathrm{G}$ & $0.70 / 0.30$ & 0.3855 & $0.91 / 0.09$ & 0.5888 \\
\cline { 2 - 3 } \cline { 5 - 6 } & $\mathrm{AA} / \mathrm{AG} / \mathrm{GG}$ & $0.50 / 0.40 / 0.10$ & & $0.84 / 0.15 / 0.01$ & \\
\hline
\end{tabular}

First nucleotide of translation start codon is designated +1; LS, Lingshan chicken; WRR, White Recessive Rock; $\chi^{2}$, Hardy-Weinberg equilibrium value.

\section{Association analysis of C.-69A>G with thermotolerance traits in WRR and LS chickens}

The association of the C.-69A $>$ G SNP with thermotolerance traits in LS and WRR chickens was analyzed under thermostress $\left(35^{\circ} \mathrm{C}\right)$ and at normal temperature $\left(15^{\circ} \mathrm{C}\right)$. The results showed that the C.-69A $>$ G SNP was significantly $(\mathrm{P}<0.05)$ associated with $\mathrm{CD} 4+/$ $\mathrm{CD} 8+$ in WRR chickens under normal temperature conditions $\left(15^{\circ} \mathrm{C}\right)$ (Table 3$)$.

Table 3. Association analysis of the C.-69A $>$ G SNP with thermotolerance traits.

\begin{tabular}{l|c|c|c|c|c}
\hline \multirow{2}{*}{ Breed/condition } & \multicolumn{5}{|c}{ Thermotolerance traits } \\
\cline { 2 - 6 } & $\mathrm{T}_{3}(\mathrm{ng} / \mathrm{mL})$ & Corticosterone $(\mathrm{ng} / \mathrm{mL})$ & $\mathrm{H} / \mathrm{L}$ & $\mathrm{CD} 3+(\%)$ & $\mathrm{CD} 4+/ \mathrm{CD} 8+$ \\
\hline LS/thermostress $\left(35^{\circ} \mathrm{C}\right)$ & 0.9020 & 0.2605 & 0.4035 & 0.7484 & 0.7420 \\
\hline WRR/thermostress $\left(35^{\circ} \mathrm{C}\right)$ & 0.8327 & 0.5901 & 0.6323 & 0.3072 & 0.3519 \\
\hline WRR/normal $\left(15^{\circ} \mathrm{C}\right)$ & 0.7536 & 0.5518 & 0.0998 & 0.5747 & $0.0132 *$ \\
\hline
\end{tabular}

$* \mathrm{P}<0.05$; LS, Lingshan chicken, WRR, White Recessive Rock. 
Association analysis between different genotypes of C.-69A $>\mathrm{G}$ and thermotolerance traits $\left(\mathrm{T}_{3}, \mathrm{H} / \mathrm{L}\right.$, corticosterone, $\mathrm{CD} 3+$, and $\left.\mathrm{CD} 4+/ \mathrm{CD} 8+\right)$ showed that WRR chickens carrying the AA genotype have a significantly higher $(\mathrm{P}<0.05) \mathrm{H} / \mathrm{L}$ value than chickens carrying the GG genotype under normal conditions (Table 4). Furthermore, WRR chickens with the AA genotype have significantly lower $(\mathrm{P}<0.01) \mathrm{CD} 4+/ \mathrm{CD} 8+$ levels than chickens with the AG genotype under normal condition (Table 4). However, no association was found under the thermostress condition $\left(35^{\circ} \mathrm{C}\right)$ in those two population.

Table 4. Association of different genotypes of the C.-69A $>$ G SNP with thermotolerance traits.

\begin{tabular}{|c|c|c|c|c|c|c|}
\hline & \multirow[t]{2}{*}{ Genotype } & \multicolumn{5}{|c|}{ Thermotolerance traits } \\
\hline & & $\mathrm{T}_{3}(\mathrm{ng} / \mathrm{mL})$ & Corticosterone $(\mathrm{ng} / \mathrm{mL})$ & $\mathrm{H} / \mathrm{L}$ & CD3+ (\%) & CD4+/CD8+ \\
\hline \multirow[t]{3}{*}{$\mathrm{LS} /$ thermostress $\left(35^{\circ} \mathrm{C}\right)$} & AA & $17.21 \pm 1.99(75)$ & $22.68 \pm 3.33(79)$ & $0.32 \pm 0.02(73)$ & $3.20 \pm 0.24(37)$ & $19.55 \pm 1.53(37)$ \\
\hline & $\mathrm{AG}$ & $17.04 \pm 2.17(63)$ & $16.22 \pm 3.67(65)$ & $0.33 \pm 0.02(60)$ & $3.27 \pm 0.26(30)$ & $19.13 \pm 1.70(30)$ \\
\hline & GG & $14.96 \pm 4.60(14)$ & $11.67 \pm 7.64(15)$ & $0.37 \pm 0.04(15)$ & $3.63 \pm 0.51(8)$ & $16.74 \pm 3.30(8)$ \\
\hline \multirow{3}{*}{$\begin{array}{l}\text { WRR/thermostress } \\
\left(35^{\circ} \mathrm{C}\right)\end{array}$} & AA & $17.60 \pm 1.73(133)$ & $40.66 \pm 3.71(122)$ & $0.28 \pm 0.02(110)$ & $3.34 \pm 0.17(67)$ & $21.53 \pm 1.79(67)$ \\
\hline & $\mathrm{AG}$ & $17.20 \pm 4.07(24)$ & $37.89 \pm 8.53(23)$ & $0.30 \pm 0.04(18)$ & $3.83 \pm 0.52(7)$ & $15.58 \pm 5.55(7)$ \\
\hline & GG & $9.03 \pm 14.11(2)$ & $11.52 \pm 28.94(2)$ & - & $5.15 \pm 1.38(1)$ & $5.64 \pm 14.69(1)$ \\
\hline \multirow[t]{3}{*}{ WRR/normal $\left(15^{\circ} \mathrm{C}\right)$} & AA & $12.40 \pm 1.20(110)$ & $27.41 \pm 2.66(106)$ & $0.32 \pm 0.01(105)^{\mathrm{a}}$ & $4.79 \pm 0.39(105)$ & $4.62 \pm 3.19(105)^{\mathrm{B}}$ \\
\hline & $\mathrm{AG}$ & $12.08 \pm 3.05(17)$ & $29.86 \pm 6.45(18)$ & $0.30 \pm 0.03(17)^{\mathrm{a} b}$ & $3.73 \pm 0.94(18)$ & $29.50 \pm 7.71(18)^{\mathrm{A}}$ \\
\hline & GG & $5.66 \pm 8.89(2)$ & $7.57 \pm 19.35(2)$ & $0.12 \pm 0.09(2)^{\mathrm{b}}$ & $5.01 \pm 2.81(2)$ & $2.150 \pm 23.12(2)^{\mathrm{AB}}$ \\
\hline
\end{tabular}

${ }^{\mathrm{a}, \mathrm{b}}$ Values within a row with no common superscript are different significantly at $\mathrm{P}<0.05$; ${ }^{\mathrm{A}, \mathrm{B}}$ Values within a row with no common superscript are significantly different at $\mathrm{P}<0.01$. LS, Lingshan chicken; WRR, White Recessive Rock. Numbers in parentheses mean tested chicken of each genotype.

\section{Association between C.-69A>G genotypes and HSP70 expression}

In the heart, leg muscle, and liver tissues, the mRNA level of $H S P 70$ varies with different genotypes of C.-69A $>\mathrm{G}$ (Figure 2). In both the heart and leg muscle, HSP70 mRNA was expressed at higher levels in individuals with the GG genotype than in those with AA and AG genotypes; however, this difference was not significant. mRNA expression of HSP70 in livers from individuals with the AA genotype was significantly $(\mathrm{P}<0.05)$ higher than in livers from those with the AG genotype.

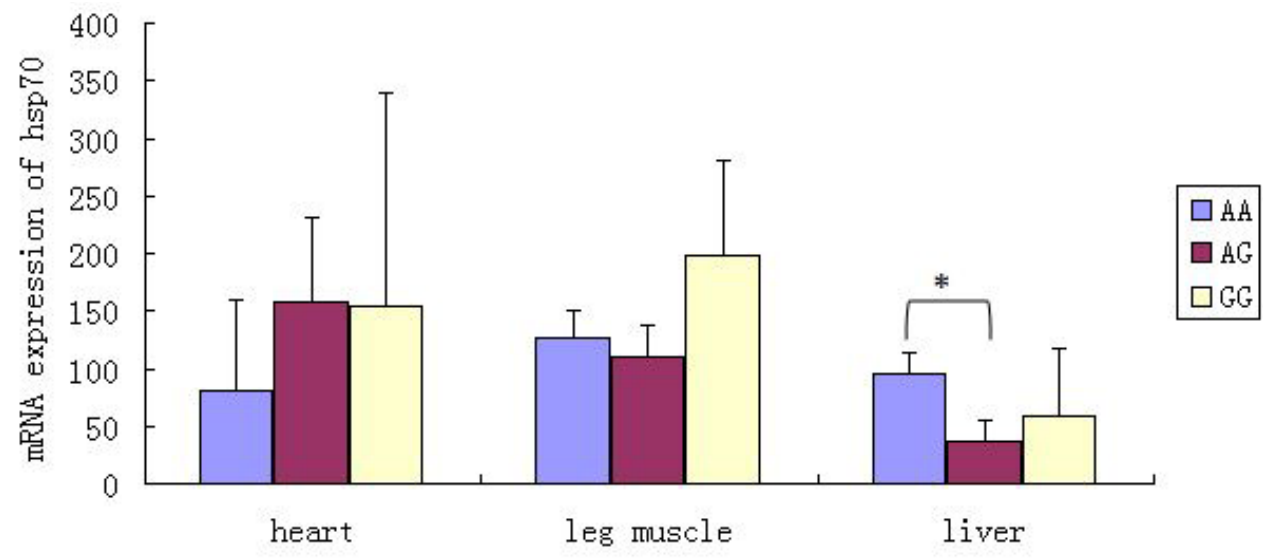

Figure 2. mRNA levels of HSP70 in individuals with different genotypes of the C.-69A $>$ G single nucleotide polymorphism. $* \mathrm{P}<0.05$. 


\section{Association of HSP70 protein expression with different C.-69A $>$ G genotypes}

The HSP70 protein was expressed at significantly $(\mathrm{P}<0.05)$ higher levels in hearts from individuals with the GG genotype than in hearts from those with the AA genotype (Figure 3). In the leg muscle, HSP70 protein expression was slightly higher in birds with the GG genotype than in individuals with the AA and AG genotypes, although this difference was not significant (Figure 3). In the liver, the level of HSP70 protein in individuals with the GG genotype was significantly higher than in individuals with the AA and AG genotypes ( $\mathrm{P}$ $<0.01$ and $\mathrm{P}<0.05$, respectively) (Figure 3). Overall, the expression of HSP70 in individuals carrying the GG genotype was higher than in those carrying the AA genotype.

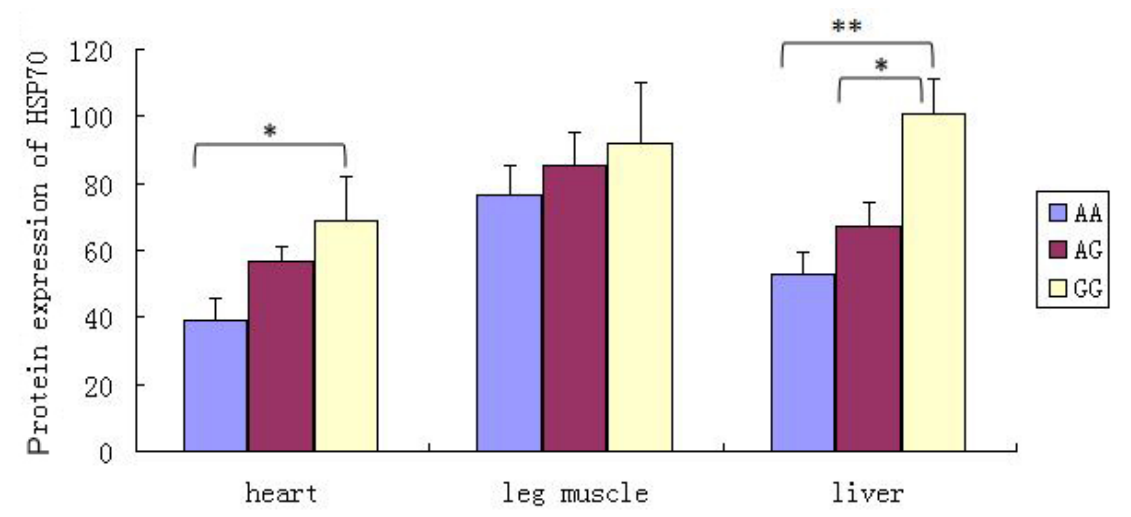

Figure 3. Protein levels of HSP70 in individuals with different genotypes of the C.-69A $>$ G SNP. $* \mathrm{P}<0.05$; $* * \mathrm{P}<0.01$.

\section{Luciferase expression assays}

Results from luciferase expression assays investigating different C.-69A $>$ G genotypes revealed that expression of the $H S P 70$ gene was significantly different $(\mathrm{P}<0.01)$ between birds with AA and GG genotypes, and in the GG genotype it was 1.37-fold affected HSP70 gene expression (Figure 4).

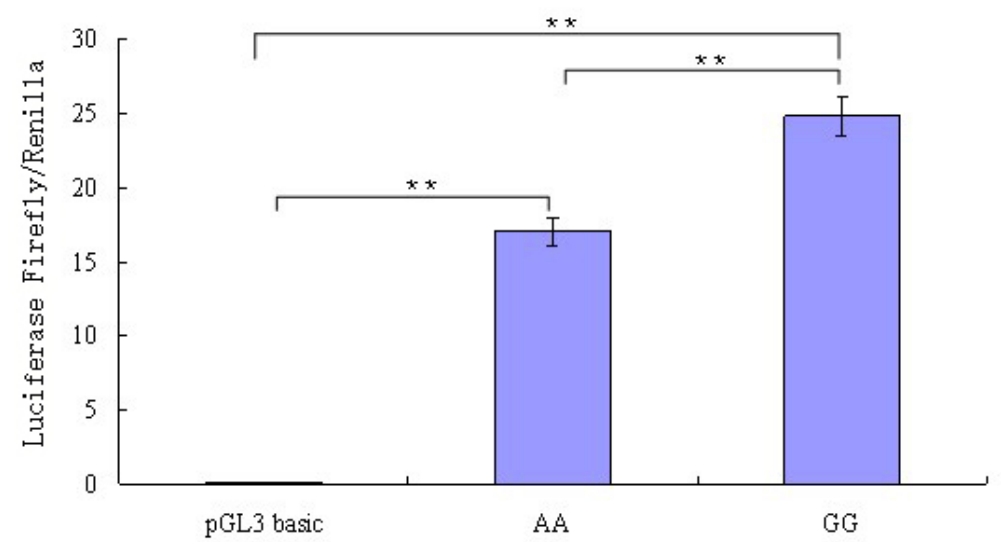

Figure 4. Luciferase expression assays for different genotypes of the C.-69A $>$ G SNP. $* * \mathrm{P}<0.01$. 


\section{DISCUSSION}

In recent years, research has shown that SNPs in both the coding and non-coding regions of genes play an important role in regulating their function, and our understanding of gene structure has expanded. SNPs in non-coding regions can regulate the binding activity of transcriptional factors by altering the structure of some transcriptional domain binding sites (Jeng et al., 2008; Shibata et al., 2009; Ucisik-Akkaya et al., 2010). Using statistical analysis, Mukai et al. (2005) found that SNP in the 5'-untranslated region of the CD40 gene had some influence on its expression, and Ordovás et al. (2008) found the g.763G $>$ C SNP in the 5'-untranslated region of the bovine FASN gene affects its promoter activity. Moreover, Sun et al. (2010) found that the rs 11868112 SNP locus on the 26-kb gene upstream of the RPTOR gene altered the RAR and POU2F1 transcription factor binding sites, which led to a decrease in gene expression (as determined by RT-PCR and ChIP methods) in response to climatic adaptations. In this study, a luciferase assay was used to show that the GG genotype was present at significantly higher levels than the AA genotype in the C.-69A $>\mathrm{G}$ site of the HSP70 gene $(\mathrm{P}<0.01)$.

Thermostress is one of the most challenging environmental conditions affecting commercial poultry (Maak et al., 2003; Cahaner et al., 2008; Melesse et al., 2011). The use of modern molecular breeding technology to identify genetic markers related to thermotolerance could allow for the possibility of direct gene selection. The potential transcription factor binding sites of C.-69A $>\mathrm{G}$ were predicted with a standard of 85 points via a TRANSFAC search on a bioinformatic website (http://motif.genome.jp). We found that variation in the C.-69A $>$ G SNP may have some effect on the regulation of HSP70 gene expression and could have an impact on the function of the HSP70 protein. Substitution of the G allele at the C.-69A $>$ G site resulted in the formation of an MZF1 binding site, which is involved in the transcriptional regulation of multiple genes, and is related to the development of the bone marrow system (Hromas et al., 1995). The frequency of the G allele was much higher in the LS chicken population than the WRR population, because the transcription factor binding site (MZF1) promoted expression of the HSP70 gene, and thus enhanced LS chicken thermotolerance.

The heart and liver are organs associated with the circulation and blood, nervous system regulation, and the functional recovery from stress damage. Under conditions of thermostress, HSP70 synthesis is increased in order to protect the circulatory system from serious injury (Hartl, 1996; Gu et al., 2012). However, changes in gene expression for other reasons should also be considered, as they may not be associated with changes in the activity of gene products. Although the qRT-PCR results showing HSP70 expression were not consistent with the results obtained by luciferase expression assays, the predicted transcription factor binding sites and results obtained by western blotting were consistent with the luciferase results. This discrepancy could be explained in two ways: 1) the sample quantity was too small, or 2) the HSP70 protein develops a biological function in the thermostress reaction. Therefore, the effect of each genotype on the expression of HSP70 can be more easily verified by determining protein and mRNA levels.

Computer analysis suggests that the 5'-flanking region of the chicken HSP70 gene contains several binding sites for putative transcription factors such as the MZF1. MZF1 is known to be involved in the development of cancer. Based on the presence of MZF1 binding sites within the promoter regions of several nuclear genes that regulate mitochondrial biogenesis (Yan et al., 2006), it is suggested that MZF1 may also play a role in regulating 
the level of HSP70 gene expression. The results of the luciferase expression assays and the predicted transcription factor binding sites suggest that the GG genotype of the C.- $69 \mathrm{~A}>\mathrm{G}$ SNP possesses an MZF1 binding site, which led to increased expression of the GG genotype over the AA genotype. Therefore, the C.-69A $>$ G SNP is thought to affect the HSP70 gene expression.

Under artificially controlled conditions, genetic equilibrium will be disrupted, affecting gene or genotype frequencies. Thus, inherited characteristics, methods of selection, and hybridization, which are important measures in animal breeding, will be altered. Surveying variation in gene and genotype frequencies in breeds that possess different traits could lead to the selection of some sites related to traits of interest (Mashaly et al., 2004). In this study, two breeds with different levels of thermotolerance were used to assess variations in gene and genotype frequencies of the C.-69A $>$ G SNP. The LS chicken is a local breed in China, which is considered to be thermotolerant, while the WRR chicken is a breed thought to possess poor thermoresistance. The frequency of the GG genotype of the C.-69A $>$ G SNP in LS chickens was much higher than that in the WRR chickens. Moreover, the distribution frequencies of the SNP C.-69A $>$ G genotypes were highly diverse $(\mathrm{P}<0.01)$ in LS and WRR chickens. This indicated that the C.-69A $>$ G SNP in two populations with different levels of thermotolerance may have undergone artificial selection during the process of selection and cultivation, with the aim of advancing thermotolerance levels.

In the current study, the C.-69A $>$ G SNP was genotyped in LS and WRR chickens, and these two breeds were used to investigate physiological and immunological traits under conditions of thermostress. Only WRR chickens were used to detect the same traits under the cited condition. Furthermore, association of the C.-69A $>$ G site with chicken thermotolerance traits was studied. Some previous studies have shown that $\mathrm{H} / \mathrm{L}$ is an important trait of cellmediated immunity, and could serve as an index for the study of stress responses and resistance (Campo and Davila, 2002). Results of the association analysis showed that the C.-69A $>\mathrm{G}$ site was significantly associated $(\mathrm{P}<0.05)$ with $\mathrm{CD} 4+/ \mathrm{CD} 8+$, and a potential association was found between the C.-69A $>$ G SNP and H/L. Furthermore, there was no difference between LS and WRR chickens with regard to $\mathrm{T}_{3}$ levels regardless of line and age, which is consistent with the results reported by Maak et al. (2003).

In summary, the results in this study suggest that the C.-69A $>$ G SNP in the 5 '-flanking region of the $H S P 70$ gene affects chicken thermotolerance traits in WRR chickens exposed to thermoneutral temperature $\left(15^{\circ} \mathrm{C}\right)$, and that the GG genotype might be advantageous for the prevention of thermostress. Thus, this SNP may be a potential molecular marker for further genetic improvement of thermotolerance in chicken.

\section{Conflicts of interest}

The authors declare no conflict of interest.

\section{ACKNOWLEDGMENTS}

We thank Professor Susan Lamont for her opinions and edits on in this manuscript. Research supported by the National Science and Technology Support Program of China (\#2014BAD08B08) and the earmarked fund for Modern Agroindustry Technology Research System (\#CARS-41). 


\section{REFERENCES}

Bedanova I, Voslarova E, Chloupek P, Pistekova V, et al. (2007). Stress in broilers resulting from shackling. Poult. Sci. 86: 1065-1069. http://dx.doi.org/10.1093/ps/86.6.1065

Benjamin IJ and McMillan DR (1998). Stress (heat shock) proteins: molecular chaperones in cardiovascular biology and disease. Circ. Res. 83: 117-132. http://dx.doi.org/10.1161/01.RES.83.2.117

Cahaner A, Ajuh JA, Siegmund-Schultze M, Azoulay Y, et al. (2008). Effects of the genetically reduced feather coverage in naked neck and featherless broilers on their performance under hot conditions. Poult. Sci. 87: 2517-2527. http:// dx.doi.org/10.3382/ps.2008-00284

Campo JL and Davila SG (2002). Estimation of heritability for heterophil:lymphocyte ratio in chickens by restricted maximum likelihood. Effects of age, sex, and crossing. Poult. Sci. 81: 1448-1453. http://dx.doi.org/10.1093/ ps $/ 81.10 .1448$

Givisiez PE, Ferro JA, Ferro MI, Kronka SN, et al. (1999). Hepatic concentration of heat shock protein $70 \mathrm{kD}$ (Hsp70) in broilers subjected to different thermal treatments. Br. Poult. Sci. 40: 292-296. http://dx.doi. $\underline{\text { org } / 10.1080 / 00071669987728}$

$\mathrm{Gu}$ XH, Hao Y and Wang XL (2012). Overexpression of heat shock protein 70 and its relationship to intestine under acute heat stress in broilers: 2. Intestinal oxidative stress. Poult. Sci. 91: 790-799. http://dx.doi.org/10.3382/ps.2011-01628

Hangalapura BN, Nieuwland MG, Buyse J, Kemp B, et al. (2004). Effect of duration of cold stress on plasma adrenal and thyroid hormone levels and immune responses in chicken lines divergently selected for antibody responses. Poult. Sci. 83: 1644-1649. http://dx.doi.org/10.1093/ps/83.10.1644

Hartl FU (1996). Molecular chaperones in cellular protein folding. Nature 381:571-579. http://dx.doi.org/10.1038/381571a0

Hartl FU and Hayer-Hartl M (2002). Molecular chaperones in the cytosol: from nascent chain to folded protein. Science 295: 1852-1858. http://dx.doi.org/10.1126/science.1068408

Hartree EF (1972). Determination of protein: a modification of the Lowry method that gives a linear photometric response. Anal. Biochem. 48: 422-427. http://dx.doi.org/10.1016/0003-2697(72)90094-2

Hromas R, Morris J, Cornetta K, Berebitsky D, et al. (1995). Aberrant expression of the myeloid zinc finger gene, MZF-1, is oncogenic. Cancer Res. 55: 3610-3614.

Jeng JE, Tsai JF, Chuang LY, Ho MS, et al. (2008). Heat shock protein A1B 1267 polymorphism is highly associated with risk and prognosis of hepatocellular carcinoma: a case-control study. Medicine (Baltimore) 87: 87-98. http://dx.doi. org/10.1097/MD.0b013e31816be95c

Jost JA, Podolski SM and Frederich M (2012). Enhancing thermal tolerance by eliminating the pejus range: a comparative study with three decapod crustaceans. Mar. Ecol. Prog. Ser. 44: 263-274. http://dx.doi.org/10.3354/meps09379

Khajavi M, Rahimi S, Hassan ZM, Kamali MA, et al. (2003). Effect of feed restriction early in life on humoral and cellular immunity of two commercial broiler strains under heat stress conditions. Br. Poult. Sci. 44: 490-497. http://dx.doi.or $\mathrm{g} / 10.1080 / 000071660310001598328$

Laemmli UK (1970). Cleavage of structural proteins during the assembly of the head of bacteriophage T4. Nature 227: 680-685. http://dx.doi.org/10.1038/227680a0

Leandro NS, Gonzales E, Ferro JA, Ferro MI, et al. (2004). Expression of heat shock protein in broiler embryo tissues after acute cold or heat stress. Mol. Reprod. Dev. 67: 172-177. http://dx.doi.org/10.1002/mrd.10397

Lu Q, Wen J and Zhang H (2007). Effect of chronic heat exposure on fat deposition and meat quality in two genetic types of chicken. Poult. Sci. 86: 1059-1064. http://dx.doi.org/10.1093/ps/86.6.1059

Maak S, Melesse A, Schmidt R, Schneider F, et al. (2003). Effect of long-term heat exposure on peripheral concentrations of heat shock protein 70 (Hsp70) and hormones in laying hens with different genotypes. Br. Poult. Sci. 44: 133-138. http://dx.doi.org/10.1080/0007166031000085319

Marques C, Guo W, Pereira P, Taylor A, et al. (2006). The triage of damaged proteins: degradation by the ubiquitinproteasome pathway or repair by molecular chaperones. FASEB J. 20: 741-743.

Mashaly MM, Hendricks GL, 3rd, Kalama MA, Gehad AE, et al. (2004). Effect of heat stress on production parameters and immune responses of commercial laying hens. Poult. Sci. 83: 889-894. http://dx.doi.org/10.1093/ps/83.6.889

Melesse A, Maak S, Schmidt R and von Lengerken G (2011). Effect of long-term heat stress on some performance traits and plasma enzyme activities in naked-neck chickens and their F1 crosses with commercial layer breeds. Livest. Sci. 141: 227-231. http://dx.doi.org/10.1016/j.livsci.2011.06.007

Mukai T, Hiromatsu Y, Fukutani T, Ichimura M, et al. (2005). A C/T polymorphism in the 5' untranslated region of the CD40 gene is associated with later onset of Graves' disease in Japanese. Endocr. J. 52: 471-477. http://dx.doi. org/10.1507/endocri.52.471

Ordovás L, Roy R, Pampín S, Zaragoza P, et al. (2008). The g.763G $>$ C SNP of the bovine FASN gene affects its promoter 
activity via Sp-mediated regulation: implications for the bovine lactating mammary gland. Physiol. Genomics 34: 144-148. http://dx.doi.org/10.1152/physiolgenomics.00043.2008

Rozenboim I, Tako E, Gal-Garber O, Proudman JA, et al. (2007). The effect of heat stress on ovarian function of laying hens. Poult. Sci. 86: 1760-1765. http://dx.doi.org/10.1093/ps/86.8.1760

Ryan MT and Pfanner N (2001). Hsp70 proteins in protein translocation. Adv. Protein Chem. 59: 223-242. http://dx.doi. org/10.1016/S0065-3233(01)59007-5

Sandercock DA, Hunter RR, Nute GR, Mitchell MA, et al. (2001). Acute heat stress-induced alterations in blood acid-base status and skeletal muscle membrane integrity in broiler chickens at two ages: implications for meat quality. Poult. Sci. 80: 418-425. http://dx.doi.org/10.1093/ps/80.4.418

Shibata T, Arisawa T, Tahara T, Yoshioka D, et al. (2009). Protective role of genetic polymorphism of heat shock protein 70-2 for gastric cancer risk. Dig. Dis. Sci. 54: 70-74. http://dx.doi.org/10.1007/s10620-008-0313-z

Staib JL, Quindry JC, French JP, Criswell DS, et al. (2007). Increased temperature, not cardiac load, activates heat shock transcription factor 1 and heat shock protein 72 expression in the heart. Am. J. Physiol. Regul. Integr. Comp. Physiol. 292: R432-R439. http://dx.doi.org/10.1152/ajpregu.00895.2005

Sun C, Southard C, Witonsky DB, Kittler R, et al. (2010). Allele-specific down-regulation of RPTOR expression induced by retinoids contributes to climate adaptations. PLoS Genet. 6: e1001178. http://dx.doi.org/10.1371/journal. pgen. 1001178

Towbin H, Staehelin T and Gordon J (1979). Electrophoretic transfer of proteins from polyacrylamide gels to nitrocellulose sheets: procedure and some applications. Proc. Natl. Acad. Sci. USA 76: 4350-4354. http://dx.doi.org/10.1073/ pnas.76.9.4350

Ucisik-Akkaya E, Davis CF, Gorodezky C, Alaez C, et al. (2010). HLA complex-linked heat shock protein genes and childhood acute lymphoblastic leukemia susceptibility. Cell Stress Chaperones 15: 475-485. http://dx.doi. org/10.1007/s12192-009-0161-6

Yan QW, Reed E, Zhong XS, Thornton K, et al. (2006). MZF1 possesses a repressively regulatory function in ERCC1 expression. Biochem. Pharmacol. 71: 761-771. http://dx.doi.org/10.1016/j.bcp.2005.12.015

Zhang X, Clark AF and Yorio T (2006). Heat shock protein 90 is an essential molecular chaperone for nuclear transport of glucocorticoid receptor beta. Invest. Ophthalmol. Vis. Sci. 47: 700-708. http://dx.doi.org/10.1167/iovs.05-0697

Zhang YQ and Sarge KD (2007). Celastrol inhibits polyglutamine aggregation and toxicity though induction of the heat shock response. J. Mol. Med. 85: 1421-1428. http://dx.doi.org/10.1007/s00109-007-0251-9

Zhen FS, Du HL, Xu HP, Luo QB, et al. (2006). Tissue and allelic-specific expression of hsp70 gene in chickens: basal and heat-stress-induced mRNA level quantified with real-time reverse transcriptase polymerase chain reaction. $\mathrm{Br}$. Poult. Sci. 47: 449-455. http://dx.doi.org/10.1080/00071660600827690

Zulkifli I, Al-Aqil A, Omar AR, Sazili AQ, et al. (2009). Crating and heat stress influence blood parameters and heat shock protein 70 expression in broiler chickens showing short or long tonic immobility reactions. Poult. Sci. 88: 471-476. http://dx.doi.org/10.3382/ps.2008-00287 